\title{
Removal of Salinity using Interaction Mangrove Plants and Bacteria in Batch Reed Bed System Reactor
}

\author{
Rachmi Layina Chimayati ${ }^{1 *}$, Harmin Sulistiyaning Titah ${ }^{1}$ \\ 1 Department of Environmental Engineering, Faculty of Civil, Environmental and Geo Engineering, Institut \\ Teknologi Sepuluh Nopember, Keputih, Sukolilo, 60111 Surabaya, Indonesia \\ * Corresponding author's e-mail: rachmi.layina@gmail.com
}

\begin{abstract}
The current method of seawater bio-desalination can effectively provide freshwater. This method works by separating the salt contained in water into clean water with a lower salinity. In this study, the researchers conducted an experiment of the bio-desalination method by combining mangrove plant and Vibrio alginolyticus bacteria as well as the presence of a filter layer component composed of sand and gravel in red beed system reactor. The concept of phytotechnology was to utilize plants as environmental technology capable of solving environmental problems. In contrast, the term phytoremediation was used to denote the process of plants absorb, take, change and release contaminants from one medium to another. The purpose of this study was to determine the reduction of salinity on the mangrove plant Rhizophora mucronata $(\mathrm{Rm})$ and Avicennia marina $(\mathrm{Am})$ with the addition of Vibrio alginolyticus (Va) bacteria in the bio-desalination process using a reed bed system. This study combines plants and bacteria for artificial saline desalination processes. The compounds contained in plants are absorbed in the form of cations or anions, while the addition of the bacteria was carried out to support the process of salt absorption in plants. The results of this study indicated a percentage of salinity decreasing up to the last day of experiment. The results showed the percentage of salinity removal at the last day reaching $49.16 \%$, and $40.58 \%$ in reed bed reactor with Avecennia marina and Vibrio alginolyticus of 15\%o and 25\%, respectively. Meanwhile, the percentage of salinity using Rhizophora mucronata showed $64.68 \%$ and $40.18 \%$ in in reed bed reactor with Rhizophora mucronata and Vibrio alginolyticus of $15 \%$ and $25 \%$, respectively. The removal of salinity also occured in the control reactor, containing only reed bed system without plant, reaching $57.36 \%$ and $58.41 \%$ in initial salinity of $15 \%$ and $25 \%$. All treatment reactors exhibited high salinity removal. It showed that the all concentrations of salinity were below $4 \%$ at Day 2 of reactor operation. It suggested that the process of desalination occurred in the entire reactor treatment. In conclusion, the reed bed system reactor can be used to treat saline water but the process of absorption of salts with mangrove plant and addition of Vibrio alginolyticus can be more stable.
\end{abstract}

Keywords: bio-desalination, mangrove, bacteria, reed bed system.

\section{INTRODUCTION}

The growing human population and technological progress of a country will encourage the demand of clean water for life. The quantity of available clean water has begun to decline due to pollution on water bodies and groundwater; thus, the efforts to find other water sources were needed. The water that can be used by humans constitutes no more than $0.5 \%$ of the approximately $16.38 \times 10^{10} \mathrm{~m}^{3}$ found above and below the Earth surface. About $97 \%$ of this amount was present in the ocean and the rest was in freshwater forms. This situation was aggravated by the process of seawater intrusion which decreases the quality of freshwater from groundwater (Saeni, 1999).

The current water desalination method can effectively provide freshwater, but this method was becoming increasingly controversial because of its negative effects on the environment, including high energy intensity and highly concentrated salt water waste. Microorganisms, the adaptation experts, have survived on Earth for millions of years without the excessive use of energy and resources 
or sacrifice of the surrounding environment. This has led scientists to study the possibility of using biological processes for seawater desalination and this field has been expanding exponentially ever since. The word bio-desalination was offered to cover all the techniques that have potential to produce freshwater from salt solutions. In addition to reviewing and categorizing the bio-desalination process for the first time, this review also reveals a research area that has not been explored in bio-desalination, which has the potential to be used in water treatment (Taheria, 2016).

The mangrove plants that grow on the beach or in brine water areas were thought to be able to desalinate seawater. It was due to the plant adaptation ability to the environment where the plant lives. Root as a part of plants can absorb nutrients and leaf, as the last destination of absorption, were thought to increase the salt content during the desalination process (Saeni, 1999).

Mangrove plants can reduce salinity in water. This desalination process aims at maintaining the balance of salt in the plant. The increased level of chloride ions in mangrove tissue were influenced by the type of mangrove; an increase occurs in the root tissue of all mangrove plants (Saeni, 1999).

The concept of phytotechnology was to utilize plants as environmental technologies that were able to solve environmental problems. In contrast, phytoremediation denotes the activity of plants including absorbing, taking, changing and releasing contaminants from one medium to another. Technology review and the processes that occur in phytoremediation, constitute a naturalbased approach to solve environmental problems (Mangkoediharjo, 2008).

Mangrove has the ability to tolerate the sea salinity and grow at above average levels (Ananthakrishnan, 1982; Flowers et al., 1977). The influence of salinity on mangrove growth was reported by Clough (1984) who states that the highest number of Avicennia marina and Rhizophora stylosa dry weight was obtained when grown at $25 \%$ seawater content. $\mathrm{He}$ also reported that $\mathrm{CI}^{-}$and $\mathrm{Na}^{+}$ion levels were greater than $\mathrm{K}^{+}, \mathrm{Ca}^{2+}$, and $\mathrm{Mg}^{2+}$ ions in mangrove plant roots, stems and leaves which grown in five different concentrations of seawater that he tried. Stem and Voigt (1959) in Tomlinson (1986) argue that it was better to use low level of seawater for breeding Rhizophora. Connor (1969) in Tomlinson (1986) found the optimum conditions for Avicennia marina growth was in a solution containing $50 \% \mathrm{Na}^{+}$ions and $\mathrm{Na}$ from seawater.

Mangrove plant was divided into two groups, namely secreter and non secreter. In the first group, including for instance Aegialitas, Aegiaceras and Avicennia, the concentration of $\mathrm{NaCI}$ in xylem latex was relatively high, but still 11:10 part of the concentration of seawater. Salt absorption occurred through the salt gland metabolism. The released salt can be crystallized through evaporation, can be blown or washed. In the second group, such as Bruguiera, Lumnitzera, Rhizophora, and Sonnerata, xylem latex contains 11: $100 \mathrm{NaCl}$ from seawater concentrations, but was still 10 times higher than non-mangrove plants. Here, removing salt was more efficient, but a few of the absorbed must be stockpiled or removed. Although the non-secreter does not have a special mechanism to actively extract salt, this plant releases salt through the leaf surface (possibly via cuticular transpiration) (Scholander et al., 1962). Vibrio sp was a type of bacteria that can live at relatively high salinity. Vibrio bacteria fluoresce including facultative anaerobic bacteria, which can live either with or without oxygen. Vibrio bacteria grows at $\mathrm{pH} 4-9$ and optimally at $\mathrm{pH}$ 6.5-8.5 or under alkaline conditions with $\mathrm{pH} 9.0$.

The aim of research was to determine the reduction of salinity in a reed bed system using the mangrove plants, Rhizophora mucronata and Avicennia marina, and combining with Vibrio alginolyticus bacteria for laboratory scale experiment. The red beed reactor was operated in batch system and on free water surface.

\section{MATERIALS AND METHODS}

\section{Materials and Tools}

This study used two species of mangrove Rhizophora mucronata, and Avicennia marina and also the Vibrio alginolyticus bacteria. The duplo reactors needed amounted to 10 units with 2 control reactors, as well as 8 reactors with the addition of bacteria and 2 reactors without plants. The saline water solution was obtained from proanalysis of $\mathrm{NaCl}$ that dissolved in aquadest with a concentration of $15 \%$ and $25 \%$. At the concentration of $15 \%$ it requires $105 \mathrm{gr} \mathrm{NaCl} /$ reactor and at $25 \%$ requires $175 \mathrm{gr} \mathrm{NaCl} /$ reactor. For the inoculation stage, NA (Nutrient Agar, Merck USA) and NB (nutrient Broth, Merck USA) 
medium were used. The bacterial requirement was $5 \%$, then bacteria required $0.15 \mathrm{~L} /$ reactor.

The composition of each reactor was as follows: gravel with a diameter of $2 \mathrm{~cm}$ and height of $5 \mathrm{~cm}$ requires $5850 \mathrm{gr}$ with $2 \mathrm{~L}$ of water, gravel with a diameter of $1 \mathrm{~cm}$ and height of $5 \mathrm{~cm}$ requires $5450 \mathrm{gr}$ with $1.8 \mathrm{~L}$ of water, and fine sand with height of $10 \mathrm{~cm}$ requires 11800 gr with $3 \mathrm{~L}$ water, while the required amount of saline water to meet the needs of $10 \mathrm{~cm}$ was $7 \mathrm{~L}$.

The reactors were made from the plastic material with the dimensions of $315 \mathrm{~mm}$ X $315 \mathrm{~mm}$ X $655 \mathrm{~mm}$. Each reactor was equipped with a drain hole on the bottom which was used as the final sampling channel for every test that was carried out every other day. The name code of each reactor can be seen in the explanation below:

- K 15: The first control reactor with concentration $15 \%$

- K 25: The second control reactor with concentration $25 \%$

- AMVA15: The biodesalination reactor with Avicennia marina and Vibrio alginolyticus in concentration $15 \%$

- AMVA25: The biodesalination reactor with Avicennia marina and Vibrio alginolyticus in concentration $25 \%$

- RMVA15: The biodesalination reactor with Rhizophora mucronata and Vibrio alginolyticus in concentration $15 \%$

- RMVA25: The biodesalination reactor with Rhizophora mucronata and Vibrio alginolyticus in concentration $25 \%$

Preparation was divided into 3 stages, the first stage was preparing the bacteria, the second stage involved preparing the plants and the last stage was preparing and assembling the reactor.

The bacterial preparation stage consists of preparing 10 grams of NA medium and 4 grams of $\mathrm{NB}$, dissolving the NA medium with an aqueous solution and heating it on a stove until it boiled. Afterwards, the medium was sterilized using an autoclave with the type of All American model number $75 x$, then the NA medium was placed on the petri dish until it thickened. Furthermore, Vibrio alginolyticus bacteria were transferred using ose $1 \mathrm{x}$ by outlining in waves in 1 line, then the entire inoculation activity had to be sterilized by working on near the fire and the ose needle must always be sterile. The bacteria then were put into the Mamert type IN55 incubator for 24 hours at a temperature of $28^{\circ} \mathrm{C}$. After growing, the bacteria were transferred to NB medium as much as 3 times ose, then shaken using an orbital shaker for 8 hours to obtain the value OD $=1$, then measured with a Thermo spectronic type genesis 20 spectrophotometer. If the value was greater than $\mathrm{OD}=1$ then the bacteria were ready to be mixed with the reactor.

The second stage was to prepare mangrove plants by separating each type of mangrove and then cleaning it by washing the remaining sludge that was attached to the roots, then acclimatizing using saline water for 24 hours.

The third stage was to arrange the reactor by filling a $2 \mathrm{~cm}$ diameter gravel with a height of 5 $\mathrm{cm}$ and saturating it with $2 \mathrm{~L}$ of water, gravel with a diameter of $1 \mathrm{~cm}$ with a height of $5 \mathrm{~cm}$ saturated by $1.8 \mathrm{~L}$ of water, and $10 \mathrm{~cm}$ of fine sand with $3 \mathrm{~L}$ of water. Afterwards the mangroves were planted as deep as $10 \mathrm{~cm}$ along the roots to the stem and saline water was added up to the height of $10 \mathrm{~cm}$. The samples were then acclimatized for 24 hours and bacteria as well as glucose solution were added to obtain the COD level of $250 \mathrm{mg} / \mathrm{L}$. Next, the measurement stage was carried out on day 0 at the inlet and outlet areas, and sampling was continued every 2 days.

The Scanning Electron Microscope (SEM) analysis was conducted on mangrove plants, $R h i$ zophora mucronata and Avicennia marina, on the last day of bio-desalination reed bed system reactor. The SEM analysis was conducted using SEM (Zeiss Model EVO MA10, Germany).

\section{RESULTS AND DISCUSSION}

This research of seawater bio-desalination process involved studying mangrove and bacterial plants for 14 days at a salinity of $15 \%$ and $25 \%$. The types of plant used in this study included Rhizophora mucronata and Avicennia marina, while the investigated bacteria was Vibrio alginolyticus. The results of the decrease of salinity in mangrove plants with the addition of bacteria indicate the salinity was reduced in the entire sample tested. This showed the occurrence of the bio-desalination process in saline water.

Figure 1 explained that Avicennia marina provides a high response to the decrease of salinity in the water and the increase in salinity in plants. This indicates that the bio-desalination process in saline water occurs in the early stages. Flowers et 
al. (1977) argue that in the early stages of adaptation to high salinity or the increase of salinity when the salt concentration in the liquid was increasing, the rate of ionic absorption was related to the growth rate of the plant. Mangrove plants take salt as nutrients for their growth needs.

The highest decrease of salinity occurred in the first 4 days, whereas in the following days there was a fluctuation due to the difference of environmental factors that occur on a daily basis. Some environmental factors included the water temperature which can affect the solubility of solutes in water, and the type of mangrove plant used. On the basis of Figure 1, all reactors showed high salinity removal. Aall concentrations of salinity were below 4\%o at Day 2 of reactor operation. This suggests that the process of desalination occurred in all reactor treatment.
Out of the two types of plants, Avicennia marina has higher ability in absorbing salt in water (Scholander et al., 1962). The results of the salinity decrease in mangroves with the addition of bacteria were the following.

The plants and Vibrio alginolyticus addition did not show a large impact on the bio-desalination process, because it was resistant to high level of salinity. These bacteria live in saline water areas and plant roots which absorb salinity. Plants that were supplemented with bacteria were able to reduce salinity and its optimal time occurred in the first 4 days, where the plants to which the bacteria were added could reduce salinity more consistently until the last day, compared to plants that were not supplemented. The bacteria performed bio-desalination process optimally only until day 4. However, the absorption rate did not

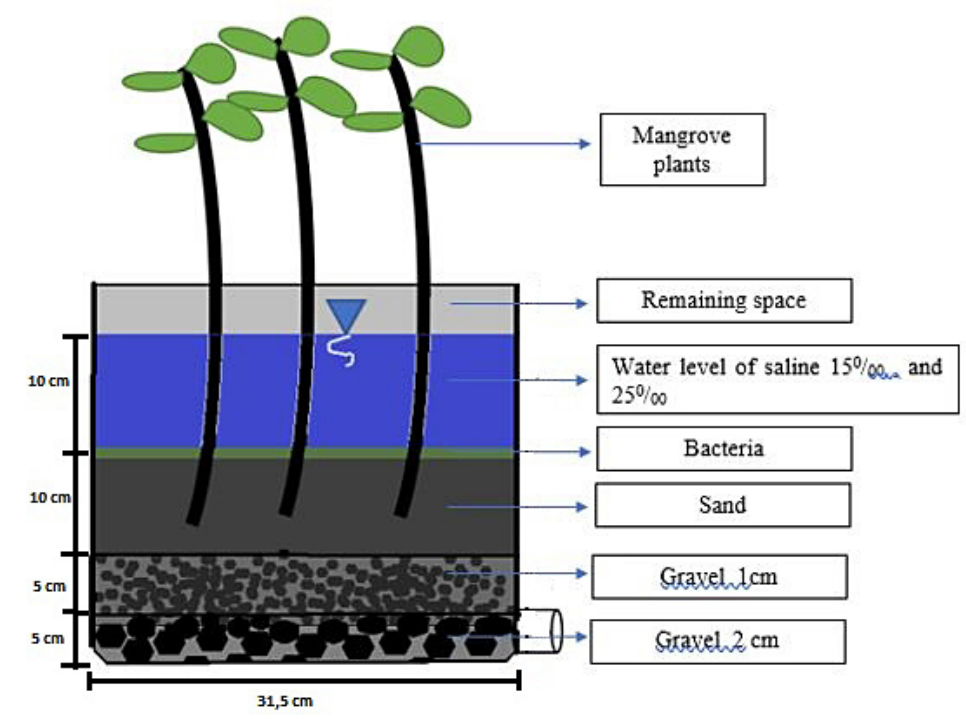

Figure 1. Design of bio-desalination reactor with mangrove and bacteria

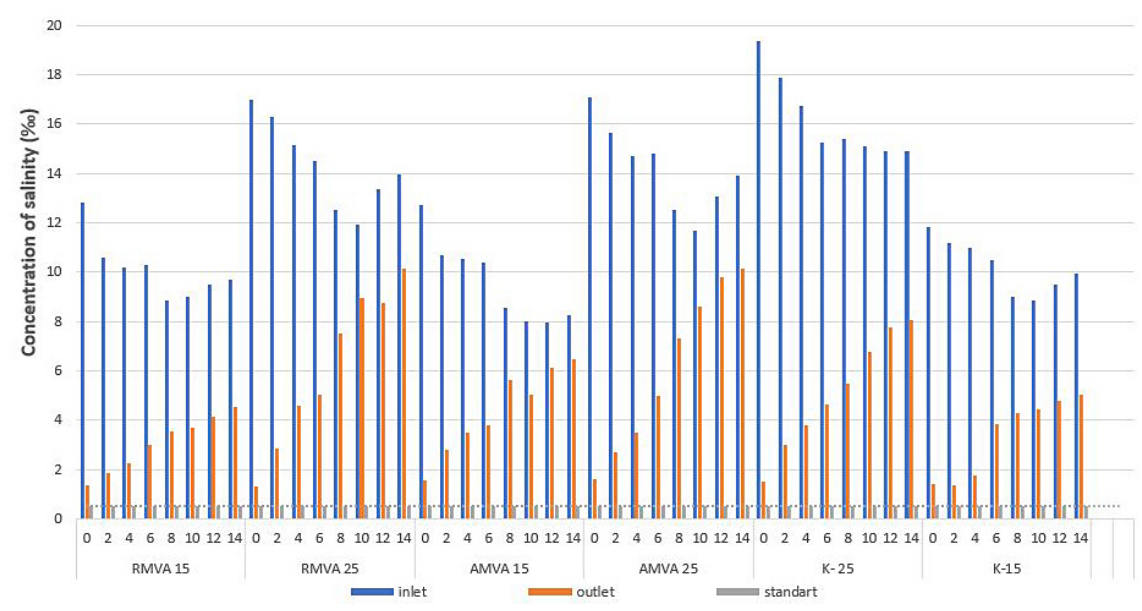

Figure 2. Results of decreasing salinity with the addition of bacteria 
have a significant impact on either of the plants that were supplemented with bacteria.

The salinity of saline water with Rhizophora mucronata has a lower value compared to Avicennia marina. This was presumably because both of them have the same taxonomy and at that saline water level both plants usually grow well. Salinity was one of the parameters in determining the water quality, for both surface and groundwater. Salinity was the level of salinity or dissolved salt contained in water in grams per litre of seawater. According to Purwanti et al. (2006), classification of the sample water for salinity parameters was divided into freshwater with a value of $<0.5 \%$, brine water with the salinity ranging from $0.5-30 \%$, salty water $30-50 \%$ and very salty water or sea water has a salinity of more than $50 \%$. The experimental results can be analysed in Figure 3

The results showed that the entire sample was still limited to the brine water area, and the optimal point of the decrease in salinity was on $0-4$ day. The previous experiment was usually performed for 12 weeks but the researcher took 14 days because this study involved an addition of Vibrio alginolyticus bacteria, whose optimal life span was only up to 14 days.

Vibrio alginolyticus bacteria was indeed found in saline water. These bacteria can grow and live in the area of plant roots which were in water that has a high level of salinity.

The results of this study indicated the percentages of salinity removal were $49.16 \%$, and $40.58 \%$ in reed bed reactor with Avecennia marina and Vibrio alginolyticus of $15 \%$ and $25 \%$, respectively. Meanwhile, the percentage of salinity showed $64.68 \%$ and $40.18 \%$ in the reed bed reactor with Rhizophora mucronata and Vibrio alginolyticus of $15 \%$ and $25 \%$, respectively. The removal of saliniy also occured in the control reactor, only containing reed bed system without plant, where it reached $57.36 \%$ and $58.41 \%$ in initial salinity of $15 \%$ and $25 \%$. . However, it can be seen that the significant results of the process occurred on days 2 and 4 where the level that can be reduced reached up to $92 \%$. It has not yet reached the freshwater standard value of $0.5 \%$. The effectiveness of bio-desalination processes occurred in the first 4 days. The decreasing of salinity also occurred in the control reactor. In this reactor, there was a decrease in salinity due to the filter of sand and gravel as well as the temperature and the $\mathrm{pH}$ factor, which resulted in salt secreted into the environment.

The $\mathrm{pH}$ and temperature were the determinants of the bio-desalination process, where the temperature and $\mathrm{pH}$ level affect the growth rate of the auxiliary bacteria in the bio-desalination process. Vibrio sp was a type of bacteria that can live in relatively high salinity. Vibrio bacteria fluoresce was facultative anaerobic bacteria, which can live either with or without oxygen. Vibrio bacteria grow at $\mathrm{pH} 4-9$ and grow optimally at pH6.5-8.5 or under alkaline conditions with a $\mathrm{pH}$ of 9.0. Vibrio bacteria could die under the acidic conditions, it was also confirmed by the results of previous studies, to obtain OD values with a wave of $600 \mathrm{~nm}$ (A) the Vibrio alginolyticus takes 2 hours to $\mathrm{pH} 8$ while for 48 hours a $\mathrm{pH}$ 5 was needed, whereas the $\mathrm{pH}$ below 5 indicates that the bacteria did not develop, exhibited by the value OD of 0 (Kurniawan et al., 2018) However,

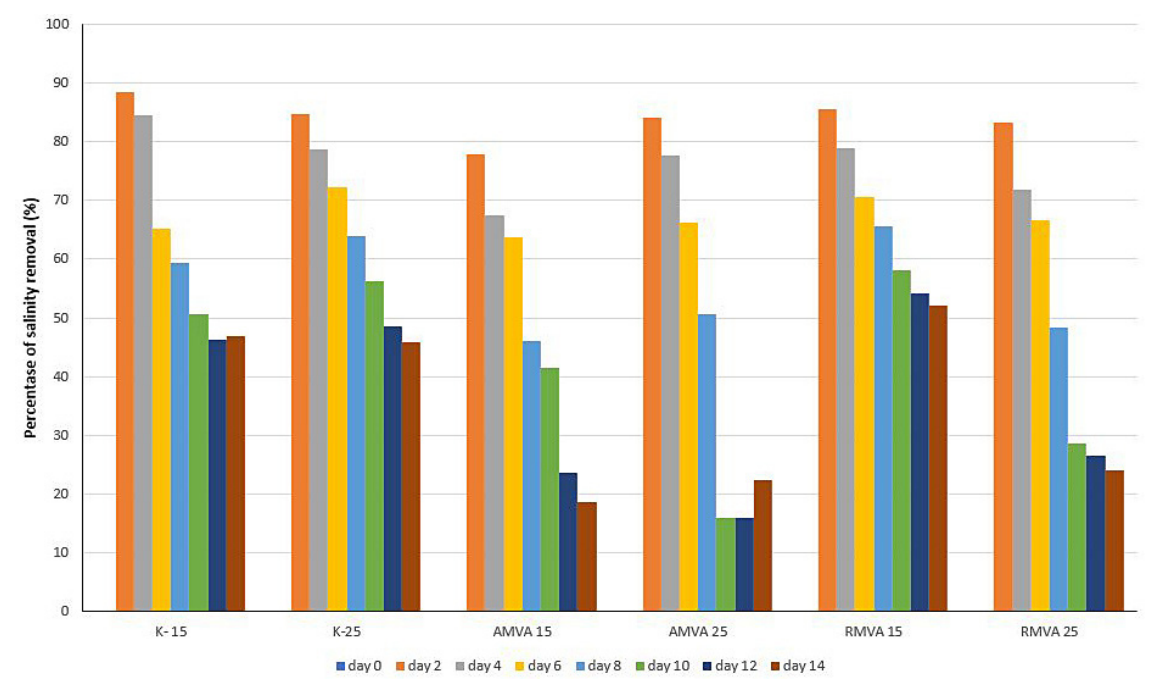

Figure 3. Results of the percentage decreasing of salinity with the addition of bacteria 


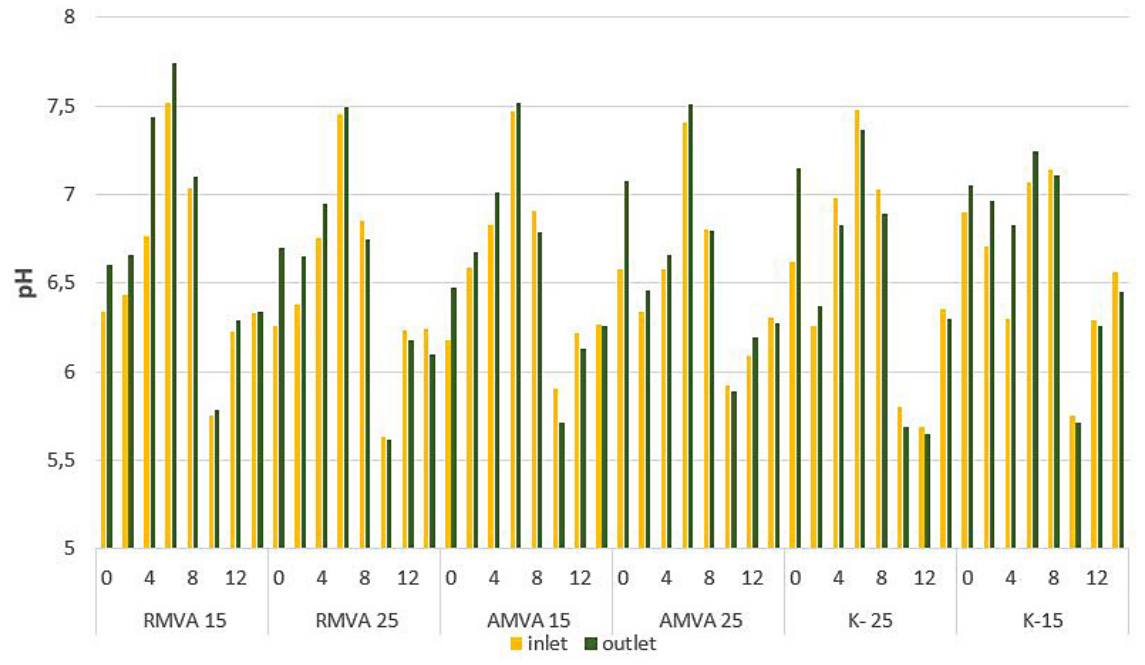

Figure 4. The $\mathrm{pH}$ value in the bio-desalination process

the presence or absence of bacteria in the biodesalination process did not affect the absorption capacity of plants in absorbing the salt content in saline water

Figure 6 illustrates the SEM results of Rhizophora mucronata and Avecennia Marina with concentrations of $25 \%$. Figure 6 indicates the sample in $300 \mathrm{X}$ zoom; the results of the sample were tested sequentially from the roots, stems and leaves of each mangrove sample. The root cells in Avecennia marina showed no damage, but root cells in Rhizophora mucronata did. Similar conditions were found in Avecennia marina with a magnification of $3000 \mathrm{X}$, being only slightly damaged. However, the stem cells in Rhizophora mucronata show considerable damage. SEM testing on the leaves did not show differences between the two samples with $300 \mathrm{X}$ magnification.
Figure 7 depicts a summary of EDX in Rhizophora mucronata and Avecennia marina roots, stems and leaves in control and salinity concentration of $25 \%$. Sodium and chloride were observed in the roots, stems and leaves of Avecennia Marina and Rhizophora mucronata. Avecennia marina has a concentration of sodium weight of $1.68 ; 0.87$ and $2.83(\%)$ in roots, stems and leaves, respectively. In turn, the chloride weight in Avecennia marina was 4.56; 1.66 and 1.94 (\%) in roots, stems and leaves, respectively. Rhizophora mucronata itself has a concentration of sodium weight of $1.47 ; 0.43$ and $0.76(\%)$ in roots, stems and leaves, respectively. The chloride weight in Rhizophora mucronata was $1.55 ; 1.14$ and $4.33(\%)$ in roots, stems and leaves, respectively.

Figure 8 shows Rhizophora mucronata and Avecennia marina can take sodium and chloride,

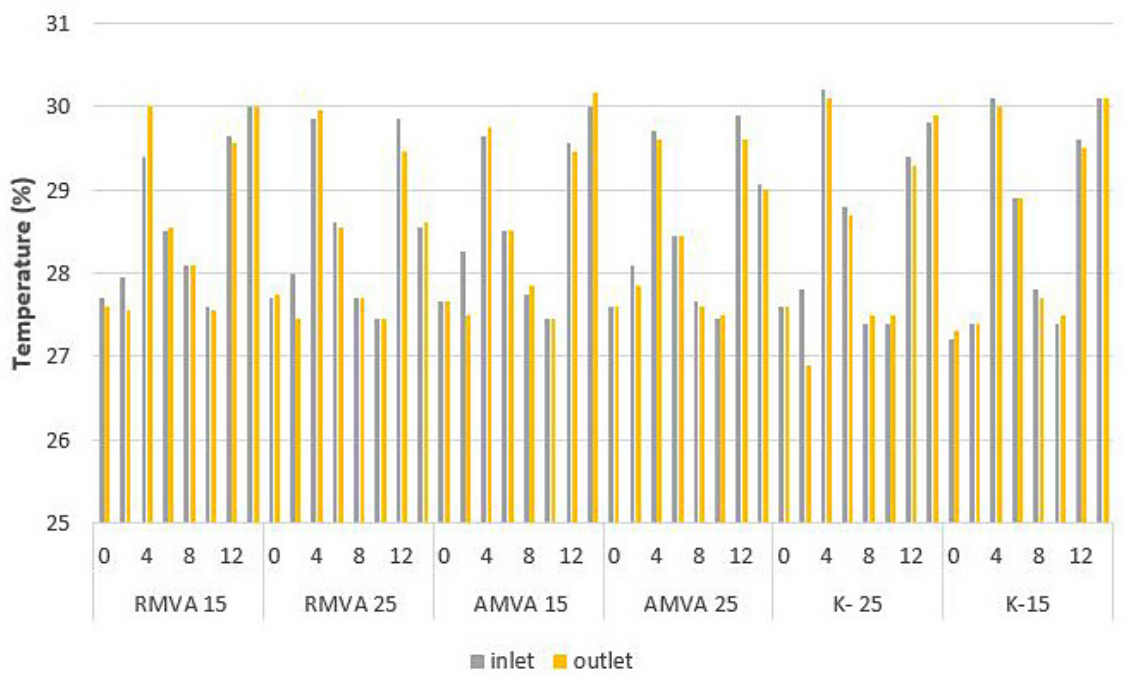

Figure 5. Temperature in the bio-desalination process 


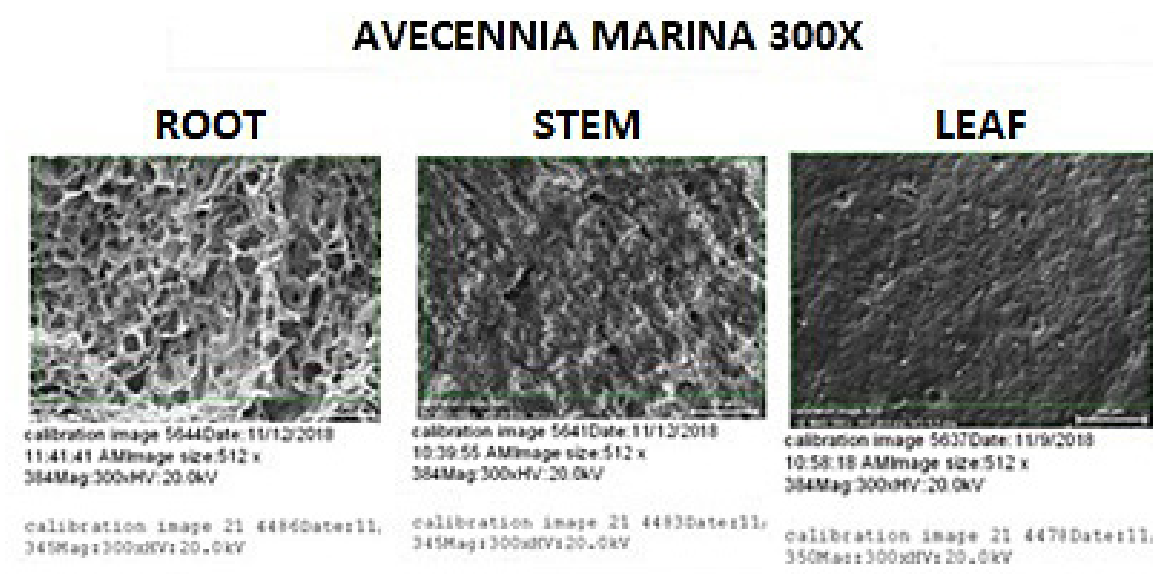

RHIZOPHORA MUCRONATA 300X
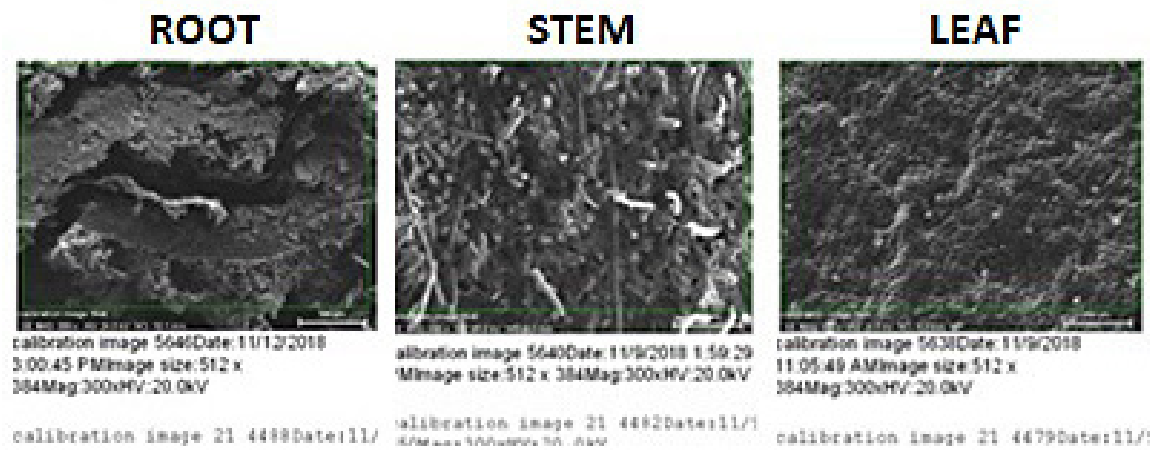

Figure 6. SEM result of Rhizophora mucronata and Avecennia marina concentrations of 250/00.

\section{AVECENNIA MARINA 300X}

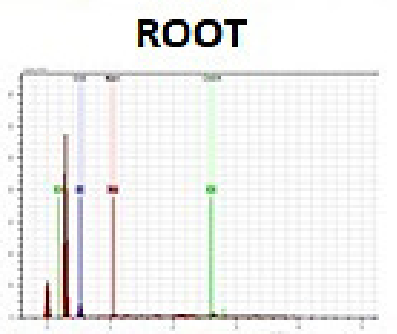

ip Datesit/s/2018 10:53:43 $\mathrm{NM}$ Duts th.: $6.20 \mathrm{k}$ epp

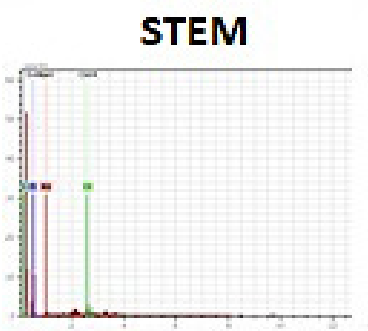

Kap Dase:11/23/2018 20141231 as Fule th.15.64kepe

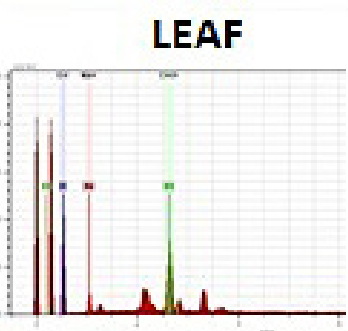

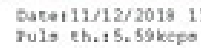

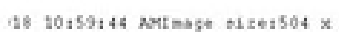

2/2018 10141131 MM5na16 size1494

1/2018 11142151 Minage 012+1496 $\mathrm{x}$

\section{RHIZOPHORA MUCRONATA 3OOX}
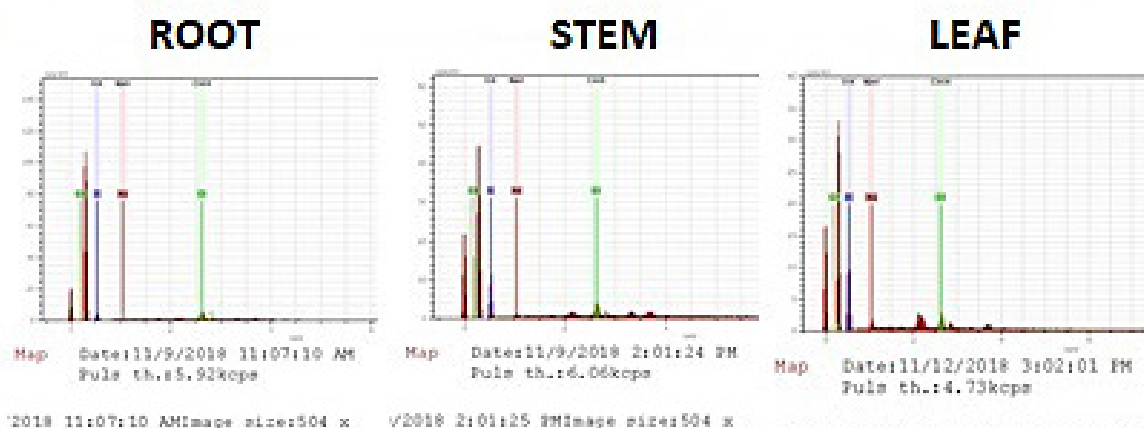

Figure 7. Graphic of EDX Rhizophora Mucronata and Avecennia Marina concentrations of 25\% 


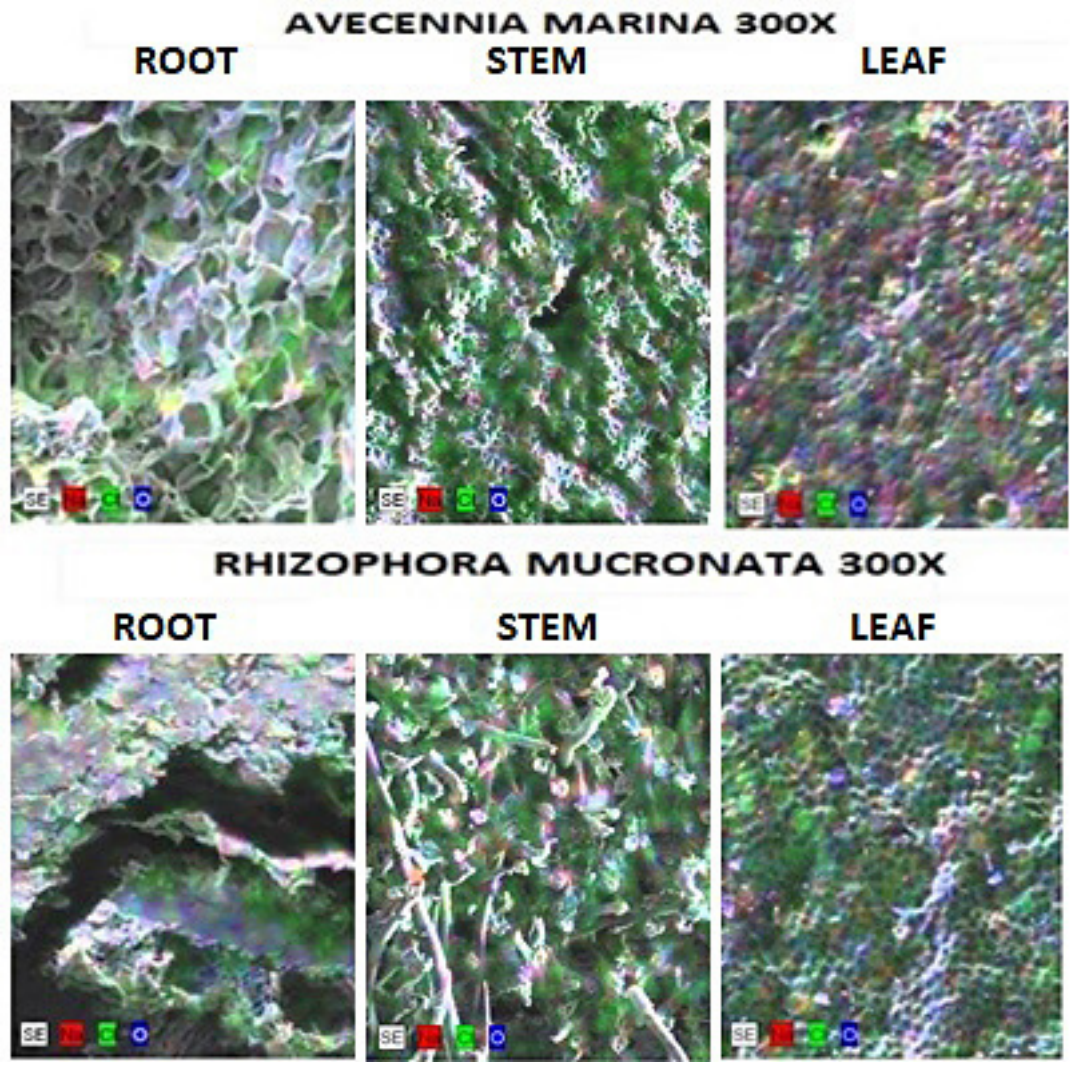

Figure 8. EDX results on roots, stems and leaves of Rhizophora mucronate and Avecennia Marina

and then, sodium and chloride were translocated to the roots, stems and leaves, from the mangrove itself. According to Popp (1994), mangroves collect high concentrations of inorganic ions like most other salt-tolerant plants that function in leaf and other tissue osmoregulation. Avicennia marina collects the highest ion concentration from Rhizophora mucronata (Scholander et al., 1962), which means that the ability of Rhizophora mucronata to accumulate inorganic ions was lower than that of Avicennia marina (Titah et al., 2019). Our previous research also showed that the Avicennia marina can accumulate high levels of sodium and chloride in their tissues. Avicennia marina has the ability to regulate the salt content by secreting it through the gland (Hegemayer, 1997 in Titah et al., 2018). Rhizophora mucronata has the ability to excrete salt through ultrafiltration of roots but does not have the ability to excrete salt through leaves (Hegemayer, 1997 in Titah et al., 2019).

\section{CONCLUSIONS}

The results showed that the percentages of salinity removal on the last day were $49.16 \%$, and $40.58 \%$ in reed bed reactor with Avecennia marina and Vibrio alginolyticus of $15 \%$ and $25 \%$, respectively. Meanwhile, the percentage of salinity showed $64.68 \%$ and $40.18 \%$ in reed bed reactor with Rhizophora mucronata and Vibrio alginolyticus of $15 \%$ and $25 \%$, respectively. The removal of salinity also occured in the control reactor, containing only reed bed system without plant, where it reached $57.36 \%$ and $58.41 \%$ in initial salinity of $15 \%$ and $25 \%$. However, it can be seen that the significant results of the process occurred on days 2 and 4 where the level that can be reduced reached up to $92 \%$. The bio-dealination processes effectiveness occurred in the first 4 days. The addition of Vibrio alginolyticus bacteria in this process does not have an effect on increasing the absorption of salinity in plants. However, the process of absorption of salts with addition of Vibrio alginolyticus can be more stable.

\section{Acknowledgements}

The author would like to thank KemenristekDIKTI through scheme of Penelitian Dasar Unggulan Perguruan Tinggi - PDUPT 2018 No. 887/PKS/ITS/2018 and No. 128/SP2H/PTHBN/ $\mathrm{DRPM} / 2018$ for funding this research. 


\section{REFERENCES}

1. Anantluikrishnan, T.N. 1982. Bioresources Ecology. Oxford \& IBH, New Delhi.

2. Bahlo, K., Wach, G. 1995. Naturnahe Abwasserreinigung - Planung und Bau von Pflanzen kläranlagen Ökobuch Verlag. Staufen bei Freiburg, 3th. Edition.

3. Brownell, P.F. 1995. The function of sodium as micro nutrients in plants. In: F.B. Salisbury \& C.W. Ross, Plant Physiology, D.R Translation. Lukman \& Sumaryono. IT Publisher Bandung.

4. Chester, R. 1989. Marine Geochemistry. Unwin Hyman, London.

5. Clough, B.F. 1984. Growth and salt balance of the mangroves Avicennia marina (Forsk) Vierh. And Rhizophora sty/osa Griff. in relation to salinitity. Aust. J. Plant Physiol., 11, 419-430.

6. Cooper, P. 1999. A Review of the Design and Performance of Vertical-Flow and Hybrid Reed Bed Treatment Systems. Water Science and Technology 40(3), 1-9.

7. Dwidjoseputro, D. 1994. Pengantar Fisiologi Tumbuhan. PT. Gramedia, Jakarta.

8. Peters E.C., N.J Gassman, J.C. Fiman R.H. Richmond and E.A. Power, 1997. 'Ecotoxicology Of Tropical Marine Ecoystem, Env.Toxicol Chem, 16, 12-40.

9. Eckenfelder W. Weslwy, 1989, Industrial Water Pollution Control, Second Edition, McGraw-Hill Book Company.

10. Farahbakhshazad, N, Morrison, G.M. 1998. Subsurface Macrophyte Systems in Wastewater Treatment. Vatten, 54, 41-51.

11. Flowers, T.J., P.F. Troke \& A.R. Yeo. 1977. The mechanism of salt tolerance in halophytes. Ann. Rev. Plant Physiol., 28, 89-121.

12. Farhan Isbir dan Razif M. 2017. Allowance for Zn metal concentrations using Mangrove Avicennia marina. Technical Journal of ITS vol 6 no 2. Department of Environmental Engineering. ITS

13. Greenway, H. 1973. Salinity plant, growt and metabolism. J. Inst. Aust. Agric. Sci., 39, 24-34.

14. Hegemeyer, J. 1997. Salt. In: Prasad, M.N.V. (ed.), Plant Ecophysiology. John Wiley \& Sons, Inc. New York, 173-206.

15. Haljadi, W. 1990. Basic Analytical Chemistry, PT. Gramedia, Jakarta.

16. Halverson, Nancy V. 2004. Review of Constructed Subsurface Flow vs. Surface Flow Wetlands, U.S. Department of Energy, Springfield, USA.

17. Hammer, D.A. (ed). 1989. Constructed Wetlands for Wastewater Treatment: Municipal, Industrial and Agricultural. Lewis Publishers,Inc: Chelsea, Michigan.
18. Imam Ghozali dan Fuad. 2008. Structural Equation Modeling. Semarang: Badan Penerbit Universitas Diponegoro.

19. Kajumulo, A. 2008. Constructed Wetlands Manual. United Nations Human Settlements Programme.

20. Khiatuddin, M. 2003. Melestarikan Sumber Daya Air Dengan Teknologi Rawa Buatan.

21. Kurniawan, S.B., Purwanti, I.F. Titah, H.S. 2018. The Effect of $\mathrm{pH}$ and Aluminium to Bacte $\neg$ ria Isolated from Aluminium Recycling Industry. Journal of Ecological Engineering,19(3), 154-161.

22. MaI, K.H. 1982. Ecology of coastal water. Studies in Ecology, vol. 5. University of California Press, Berekeley-California.

23. Mangkoedihardjo, S. 2008. Fitotechnology Integrity in Environmental Sanitation for Sustainable Development. Speech Manuscript Inauguration of Professor of Environmental Sanitation and Phytotechnology. Faculty of Civil Engineering and Planning, Environmental Engineering Department. Sepuluh Nopember Institute of Technology Surabaya. January 26, 2008.

24. Mic Millan, C. 1974. Salt toleranceof mangroves and submerged aquaric plants. Dalam R.J. Reimold \& W.H. Queen (penyunting) Ecology of Halophytes. Academic Press, New York.

25. Metcalf \& Eddy. 1993. Wastewater Engineering Treatment Disposal Reuse, McGraw-Hill Inc., New York.

26. Nybakken, I.W. 1992. Marine Biology: An ecological approach. Translation M. Eidman, Koesbiono, D.G. Bengen, M, Hutomo \& S. Sukardjo. PT. Gramedia, Jakarta.

27. Piper, C.S. 1947. Soil and Plant Analysis. Interscience Publishers, New York.

28. Platzer, C. 1998. Entwicklung eines Bemessungsansatzes zur Stickstoffelimination in Pflanzenkläranlagen Dissertation, Institut für Siedlungswasserwirtschaft. TU, Berlin.

29. Prawiranata, W.,S. Harran \& P. Tjondronegoro. 1995. Basics of Plant Physiology, JId. 2. Department of Botany, FMIPA-IPB, Bogor.

30. Purwanti, I,F., Anjasmara I,R., and Suharmadi, 2006. Groundwater salinity modeling in East Surabaya. Proceedings of the National Seminar on Technology Management III. Department of Environmental Engineering, ITS, Surabaya.

31. Reed S.C., Crites R.W., Middlebrooks E.J. 1995. Natural Systems for Waste Management and Treatment. 2nd ed., McGraw-Hill Inc., New York.

32. Reno, C.E. 1970. Investigating Water Problems: A Water Analysis Manual. La Motte Chemical Product, Maryland.

33. Respati Bintang dan Sulistiyaning Harmin. 2017 Ability of Avecianna Alba to Reduce Copper $(\mathrm{Cu})$ 
Concentration in Wonorejo River Estuary, Surabaya. Technical Journal of ITS vol 6 no 2. Department of Environmental Engineering. ITS.

34. Saeni, M.S. 1999. Seawater Desalination with Mangrove Plants. Patimura University. Ambon

35. Saeni, M.S. 1986. The ability of sand, palm fiber and charcoal filters to improve the physical and chemical quality of the Ciliwung watershed. Doctoral Thesis. Pascasaljana Faculty, Bogor Agricultural Institute.

36. Saeni, M.S. 1989a. Physical Chemistry I. PAU IImu Hayat-IPB, Bogor.

37. Saeni, M.S. 1989b. Chemical environment. PAU IImu Hayat-IPB, Bogor.

38. Salisbury, F.B. \& · C.W. Ross. 1995. Plant Physiology, Jld. 1. Translation D.R. Lukman \& Sumaryono.Perberbit ITB, Bandung.

39. Sarifah H., et al. 2017. Analysis of Heavy Metal Content of $\mathrm{HG}$ and $\mathrm{Cu}$ Dissolved in Wonorejo Coastal Waters, East Coast Surabaya. Journal of Geography Education. Brawijaya University.

40. Scholander, P.F. 1968. How mangroves desaline seawater. Physiol. Plant., 21:251-261.

41. Scholander, P.F., H.T. Hammel, E. Hemmingsen, \&. Carey. 1962. Salt balance in mangroves. Plant Physiol., 37, 722-729.

42. Soerianegara, I. 1990. The rational use of mangroves for various purposes. In the Southeast Sulawesi Coastal Resources Potential. Work Gathering Proceedings. Research Institute for Balitbang Beach Cultivation in Agriculture, Ministry of Agriculture.

43. Sugiarto, A. 1984. The mangroves ecosystem in Indonesia, its problems and management. Dalam H.J. teas (penyunting). Physiology and management of mangroves. Dr. W. Junk Publishers, The Hague.

44. Suriawiria, U. 1993. Mikrobiologi Air. Penerbit Alumni: Bandung

45. Taheri Reza, DKK. 2016. Biodesalination - On harnessing the potential of nature's desalination processes. IOP Publishing Ltd.

46. Taheria, R., Razmjoua, A., Szekelyb, G., Houc, J.,
Ghezelbash, R. 2016. Biodesalination - on harnessing the potential of nature's desalination processes. IOP Publishing Ltd.

47. Tchobanoglous, GeorgedanFranklinL.Burton,2003, Wastewater Engineering Treatment, Disposal and Reuse fourth edition, Mc. Graw Hill Inc, Singapore

48. Terry, N. 1977. Photosysthesis, growth, and the role of chloride. Plant Physio., 60, 69-15.

49. Titah H.S., et al., 2018a. Preliminary Phytotoxicity Test On Salinity Against Mangrove Plants Of Rhizophora Mucronate. Department of Environmental Engineering, ITS, Surabaya.

50. Titah H.S., et al.,. 2018b. Range Finding Phytotoxicity Test Osf Salinity On Avicennia Marina As The Step On Bio-Desalination Technology. Department of Environmental Engineering, ITS, Surabaya.

51. Titah, H.S., Abdullah, S.R.S., Idris, M., Anuar, N., Basri, H. and Mukhlisin, M. 2013. Effect of applying rhizobacteria and fertilizer on the growth ofLudwigia octovalvis for arsenic uptake and accumulation inphytoremediation. Ecological Engineering, 58, 303-313.

52. Titah H.S, Pratikno, H., Chimayati, R.L 2018. Range Finding Phytotox $\neg$ icity Test of Salinity on Avicennia Marina as The Step On Bio-Desalination Technology. International International Conference Science \& Technology - ICST, Faculty of Science \& Technology Airlangga University.

53. Titah H.S, Purwanti, I.F., Pratikno, H., Chimayati, R.L., Handayanu. 2019. Preliminary Phytotoxicity Test on Salinity Against Mangrove Plants of Rhi $\neg$ zophora Mucronate. Journal of Ecological Engineering, 20(3), 126-134.

54. Tjandhana \& E. Punvanto 1995. Indonesian mangrove forests. Jungle Ambassadors 177-178 / XX:2-9

55. Tomlinson, P.B. 1986. The botany of mangroves. Cambridge University Press, Cambridge.

56. Vymazal J., Brix H., Cooper P.F., Green M.B., Haberl R. 1998. Constructed Wetlands for Wastewater Treatment in Europe. Backhuys Publishers: Leiden. 